\title{
Estrogen, astrocytes and the neuroendocrine control of metabolism
}

\author{
E. Fuente-Martin • C. Garcia-Caceres • E. Morselli • \\ D. J. Clegg • J. A. Chowen • B. Finan • R. D. Brinton • \\ M. H. Tschöp
}

Published online: 6 September 2013

(C) The Author(s) 2013. This article is published with open access at Springerlink.com

\begin{abstract}
Obesity, and its associated comorbidities such as type 2 diabetes, cardiovascular diseases, and certain cancers, represent major health challenges. Importantly, there is a sexual dimorphism with respect to the prevalence of obesity and its associated metabolic diseases, implicating a role for gonadal hormones. Specifically, estrogens have been demonstrated to regulate metabolism perhaps by acting as a leptin mimetic in the central nervous system (CNS). CNS estrogen receptors (ERs) include ER alpha $(E R \alpha)$ and ER beta $(E R \beta)$, which are found in nuclear, cytoplasmic and membrane sites throughout
\end{abstract}

E. Fuente-Martin $\cdot$ C. Garcia-Caceres $\cdot$ B. Finan $\cdot$ M. H. Tschöp Institute for Diabetes and Obesity, Helmholtz Zentrum München and Department of Medicine, Technische Universität München, Munich, Germany

E. Morselli • D. J. Clegg

Department of Internal Medicine, University of Texas Southwestern Medical Center, Dallas, TX, USA

\section{J. A. Chowen}

Hospital Infantil Universitario Niño Jesús, Department of Endocrinology, Instituto de Investigación La Princesa, Madrid, Spain

\section{J. A. Chowen}

Centro de Investigación Biomédica en Red (CIBER) de la

Fisiopatología de Obesidad y Nutrición, Instituto de Salud Carlos III, Madrid, Spain

\section{R. D. Brinton}

Department of Pharmacology and Pharmaceutical Sciences, University of Southern California, Los Angeles, CA, USA

\section{H. Tschöp ( $\square)$}

Institute for Diabetes and Obesity, Helmholtz Center Munich, HelmholtzZentrum München, German Research Center for Environmental Health ( $\mathrm{GmbH})$, Ingolstaedter Landstr. 1, 85764 Neuherberg/Munich, Germany

e-mail: matthias.tschoep@helmholtz-muenchen.de

URL: www.helmholtz-muenchen.de the brain. Additionally, estrogens can bind to and activate a $\mathrm{G}$ protein-coupled estrogen receptor (GPER), which is a membrane-associated ER. ERs are expressed on neurons as well as glia, which are known to play a major role in providing nutrient supply for neurons and have recently received increasing attention for their potentially important involvement in the CNS regulation of systemic metabolism and energy balance. This brief overview summarizes data focusing on the potential role of astrocytic estrogen action as a key component of estrogenic modulation responsible for mediating the sexual dimorphism in body weight regulation and obesity.

Keywords Obesity · Sexual dimorphism · Estrogens · Leptin $\cdot$ Astrocytes

\section{Introduction}

Obesity has become a global health challenge of staggering proportions, and its prevalence continues to increase. Obesity is associated with comorbidities including type 2 diabetes, the metabolic syndrome, cardiovascular disease, cancer, sleep apnea and osteoarthritis [1]. Obesity is believed to be associated with a pattern of moderate but chronic inflammatory processes in both peripheral organs and the central nervous system (CNS), which contributes to leptin and insulin resistance [2].

Obesity affects males and females differently. The metabolic response to dietary regimes and pharmacological treatments for obesity differ between the sexes [3-9]. Differences in the levels of circulating gonadal steroids are critical for many of the sexually dimorphic characteristics. Estrogens are sex steroid hormones with known essential roles in reproduction, but additionally, estrogens mediate protective actions against body weight gain and metabolic diseases [10-15]. Estrogens exert their influence on diverse target tissues, including the CNS where they bind and activate receptors in 
neurons and astrocytes [16-18]. These sex steroids also have neuroprotective and anti-inflammatory actions in the CNS, with some of these actions being mediated by effects on glial cells $[19,20]$, which express both estrogen receptors (ER) isoforms, $\mathrm{ER} \alpha$ and $\mathrm{ER} \beta$ [21]. Astrocytes participate in diverse neuroendocrine functions $[22,23]$, including CNS regulation of systemic metabolism as well as in the pathogenesis of metabolic diseases [24-26]. Although the role of estrogens in the control of energy balance has been studied extensively, the exact neuroendocrine circuits and intracellular signaling pathways implicated in estrogenic neuroendocrine regulation of systemic metabolism remain to be completely characterized. This review provides a brief overview of the potential role of neuroendocrine estrogen signaling as a mediator of the sexual dimorphism in body weight regulation and obesity with a specific focus on the emerging role of estrogen action in astrocytes.

\section{Sexual dimorphism and metabolic control}

Males and females differ in where body fat is stored, endocrine secretory patterns, and how the brain responds to hormonal signals that regulate food intake and body weight [13, $14,27,28]$. Sex differences in body fat distribution are evident after puberty $[29,30]$. Females predominantly accumulate subcutaneous body fat, resulting in a "pear" shape, while males deposit more body fat viscerally, resulting in an "apple" shape [31]. However, these sex differences in body fat distribution diminish after estrogen deficiency caused by menopause. Post-menopausal females tend to accumulate more visceral fat and become more susceptible to metabolic disorders than pre-menopausal women $[32,33]$.

The sexual dimorphism in fat content and distribution has functional implications in regulating body weight [7]. Body adiposity and body fat distribution are factors that contribute to determining baseline levels of circulating cytokines and adipokines, such as leptin [34], and regulate hormone sensitivity, inflammatory responses, and even circulating levels of steroids [7]. However, the sexual dimorphism in body weight cannot be explained only by differences in body fat composition. For instance, circulating leptin levels are higher in females than males, regardless of body fat content [35-37], and sex steroids are involved in the modulation of leptin levels [38]. Taken together, these findings suggest that sex hormones, potentially estrogens, may be involved in body weight homeostasis.

\section{Role of estrogens in metabolic control}

Estrogens act as modulators of metabolism by regulating body weight, fat storage, energy expenditure, feeding behavior and glucose and lipid metabolism in both sexes $[10-13,15,27$, 39-42]. Estrogens exert their actions predominantly through two ERs, ER $\alpha$ and ER $\beta$, which are classically thought to act as nuclear receptors [43]. Acting as transcription factors, ERs regulate numerous downstream genes, including those involved in cell cycle regulation, proliferation and apoptosis [44]. In addition to their actions as nuclear transcription factors, a portion of estrogen-induced signaling can be attributed to an extranuclear, non-genomic pathway and the activation of rapid phosphorylation cascades, which, in addition to membrane-associated ER $\alpha$ and ER $\beta$ (mERs), may be mediated via the $G$ protein-coupled ER (GPER).

Circulating levels of $17 \beta$-estradiol $\left(E_{2}\right)$, the major physiological form of estrogen, correlate inversely with visceral fat mass [45], protecting against adipose accumulation and diminishing pro-inflammatory signaling [11, 39, 40, 42]. The loss of $E_{2}$, either from menopause [41, 42], ovariectomy (OVX) [11], or the inactivation of aromatase, an enzyme essential for $\mathrm{E}_{2}$ synthesis [46], leads to increased food intake and adiposity, both of which can be reversed by physiological $E_{2}$ replacement [47]. These restorative effects of $E_{2}$, however, are blocked in $\mathrm{ER} \alpha$ knockout $(\mathrm{ER} \alpha \mathrm{KO})$ mice regardless of sex [15]. Moreover, intracranial injection of $\mathrm{E}_{2}$ in rats leads to anorexia. These observations indicate that $\mathrm{E}_{2}$, similar to leptin, has direct anorexigenic functions in the CNS, specifically in the ventral medial (VMN) and arcuate nuclei (ARC) of the hypothalamus $[48,49]$.

The hypothalamus plays a key role in controlling energy and weight homeostasis. This brain area receives afferent and sends efferent messages to the periphery in order to regulate body weight by precisely balancing the intake of food, energy expenditure and nutrient deposition in adipose tissue. Early studies showed how lesions in specific hypothalamic nuclei, such as the VMH $[50,51]$ or the lateral hypothalamic area (LH) [52-54] produced drastic changes in food intake and body weight. More recently, studies have identified other hypothalamic sites, like the ARC, as key targets for hormonal and neuropeptide signals involved in sensing and controlling energy homeostasis [55].

$E_{2}$ acts on the hypothalamus through its specific receptor subsets, which are expressed in several hypothalamic nuclei, including the ARC and the VMH. ER $\alpha$ is more abundantly expressed throughout the whole brain compared to ER $\beta$, which coincides with ER $\alpha$ being considered the more relevant ER for regulating energy homeostasis. Mice with mutations in $\mathrm{ER} \alpha$ are obese [56] and resistant to the restorative effects of $E_{2}$ replacement [15], whereas mice with ER $\beta$ deletions maintain a normal body weight [57]. However, ER $\beta$ appears to act as a modulator of $E_{2}$ actions in the brain since the hypophagic effect of central $E_{2}$ is blunted by ER $\beta$ gene manipulation [58]. $\mathrm{ER} \alpha$ is more abundant in the ARC compared to other relevant nuclei and is predominantly expressed in pro-opimelanocortin (POMC) neurons [48, 59]. Increased circulating estrogens are 
directly correlated with ER $\alpha$ mRNA levels in ARC POMC neurons [60] and synaptic input to these neurons [47]. ER $\alpha$ signaling in these ARC POMC neurons appears to mediate a degree of the anorectic actions of estrogens as the selective deletion of $E R \alpha$ in these neurons results in hyperphagia without altering energy expenditure [48]. Conversely, silencing of ER $\alpha$ in the VMH using RNA interference [61] or selective deletion in steroidogenic factor-1 (SF-1) neurons [48] leads to obesity and glucose intolerance as the consequence of reduced energy expenditure with no effect on food intake, which suggests a neuroanatomical segregation of the homeostatic effects of $E R \alpha$ [48].

In addition to its central actions, estrogen signaling also regulates certain peripheral hormones, such as leptin, that influence feeding, meal size and thermogenesis through their actions in the CNS. Leptin is a metabolic hormone, which is generally believed to cross the blood-brain barrier (BBB) to interact with leptin receptors in the hypothalamus and brainstem [62-68], resulting in the inhibition of food intake and increased energy expenditure [63, 65, 67-73]. Although there are at least six alternatively spliced isoforms of the leptin receptor, the long form of the leptin receptor $(\mathrm{OB}-\mathrm{Rb})$ is the one primarily involved in metabolic control [74]. Ob-Rb co-localizes with $\mathrm{ER} \alpha$ in the ARC [75], suggesting a coordinated interaction, and $\mathrm{ARC} \mathrm{Ob}-\mathrm{Rb}$ mRNA is, in fact, modulated by estrogens [76]. Females have higher circulating levels of leptin compared to males, and these levels are independent of differences in body composition [35-37]. Leptin sensitivity in females varies throughout life depending on basal levels of estrogens, with a direct relationship between estrogen levels and hypothalamic leptin sensitivity [77, 78]. $\mathrm{E}_{2}$ treatment of both males and OVX females increases central leptin sensitivity [78], indicating a relevant interaction between leptin and $\mathrm{E}_{2}$, with both hormones exerting similar patterns of metabolic actions in the hypothalamus [47, 79].

\section{Role of hypothalamic astrocytes in the control of metabolism}

Astrocytes are the most abundant glial cells in the mammalian brain. After the first descriptions of glia as passive supporters of neurons [80], data in subsequent years have revealed considerable evidence suggesting that glia are actively involved and required for effective function of the CNS. Glia are critical to synaptic transmission, regulation of neural immune responses, antioxidant defense, structural and nutritive support of neurons, and neuronal survival [81-87].

The role of glial cells in metabolic control and obesity is an active area of investigation [2, 24-26, 88]. Hypothalamic astrocytes play a crucial role in brain homeostatic control of metabolism due in part to their strategic location close to the
BBB. These cells transport and release many substances (e.g. ions, glucose, lactate, fatty acids, ketone bodies) from the peripheral circulation into the brain to provide nutrients for neurons and regulate the extracellular environment $[84,89,90]$. It is well known that hypothalamic neurons respond to hormones and possess the respective receptors, but astrocytes also express receptors for some of the same hormones involved in metabolic control, including leptin and estrogens [21, 91-96].

Astrogliosis, a reactive phenotype of astrocytes characterized by the up-regulation of structural glial proteins such as glial fibrillary acidic protein (GFAP) and vimentin [97], has been detected in the hypothalamus of high fat diet-induced obese rodents [24, 25], and precedes weight gain [25]. Astrogliosis is known to be associated with tissue injury and neurodegenerative diseases $[98,99]$. However, the potential role of such reactive gliosis in the pathogenesis of metabolic diseases such as obesity has not yet been clarified. Hypothalamic astrogliosis in obese mice is accompanied by increased cytokine expression [25], weakened leptin signaling in hypothalamic neurons and increased astrocytic ObR expression $[91,100]$, suggesting that astrocytes are involved in the regulation of leptin signaling.

\subsection{Astrocytic estrogen action and metabolic control}

Astrocytes are targets for estrogen action [20, 101-105] as reflected by the fact that astrocytes express both ER $\alpha$ and ER $\beta$ receptors either on their plasma membranes or intracellularly [21, 92-96]. Activation of the mER initiates a rapid, free cytoplasmic calcium concentration $\left(\left[\mathrm{Ca}^{2+}\right]\right)$ flux via the phospholipase $\mathrm{C}$ (PLC)/inositol trisphosphate $\left(\mathrm{IP}_{3}\right)$ pathway [96]. Recently, the transmembrane ER, G protein-coupled estrogen receptor (GPR) 30, was reported to mediate nongenomic and rapid estrogen signaling in astrocytes [106-108], contributing to the neuroprotective effects of $E_{2}$. Despite these reports, ER $\alpha$ appears to be primarily responsible for the signaling in astrocytes [94, 101, 108, 109]. Kuo and colleagues observed that the $\mathrm{E}_{2}$-induced $\left[\mathrm{Ca}^{2+}\right]$ response was significantly attenuated in ER $\alpha \mathrm{KO}$ mouse astrocytes, suggesting $E_{2}$ signaling through $m E R \alpha$. Furthermore, PPT, a selective $\mathrm{ER} \alpha$ agonist, induced similar $\left[\mathrm{Ca}^{2+}\right]$ responses to $\mathrm{E}_{2}$ in astrocytes and glial progesterone synthesis is equally facilitated by PPT and $\mathrm{E}_{2}$ [108].

Some effects of estrogens on astrocytes are sexually dimorphic. Specifically, the astrocyte-derived synthesis of steroids, which is necessary for positive estrogen feedback [103], is increased in females but not males in response to $E_{2}$ stimulation [110]. Likewise, astrocytes respond to $\mathrm{E}_{2}$ stimulation by elevating the $\left[\mathrm{Ca}^{2+}\right]$ levels in both sexes, but this stimulation is less powerful in males [109]. Moreover, $E_{2}$ increases the amount of $E R \alpha$ at the cell membrane of astrocytes, but only in adult females [110]. These results support the hypothesis 
that astrocytes respond to hormones in a sexually dimorphic way [111, 112].

The majority of studies examining the central effect of estrogen on astrocytes have focused on anti-inflammatory actions [20, 113-115]. Specifically, estrogens are capable of reducing the expression of several inflammatory markers, such as interleukin 6 (IL-6), interferon $\gamma$-inducible protein 10 (IP-10) and NFKB, in cultured astrocytes [20, 114, 116-118]. Estrogens also regulate the expression of astrocytic molecules that are involved in the regulation of neuroendocrine events in the hypothalamus, such as growth factors [119] and glutamate transporters (GLT-1 and GLAST) [94], the expression of which increases in response to activation of GPR 30 by $E_{2}$ [120]. However, little is known about the effects produced by estrogen on hypothalamic astrocytes in metabolic disorders such as obesity.

Estrogens are involved in metabolic control, not only controlling fat stores but also modulating central leptin sensitivity
[28]. $E_{2}$ supplementation helps overcome central leptin resistance in diet-induced obesity [121]. Centrally-delivered estrogen, in the form of a GLP-1-estrogen conjugate, attenuates leptin resistance and reverses the metabolic syndrome in diet induced obese mice [122]. Moreover, the regulation of leptin signaling appears to be mediated by hypothalamic astrocytes [91], which, as mentioned above, are important estrogen targets in the CNS. These novel findings indicate that estrogens could act directly on astrocytes to ameliorate leptin resistance and control body weight through hypothalamic glial signals. In addition, since obesity produces a state of both peripheral and central inflammation, the estrogenic regulation of astrocytic proinflammatory cytokine secretion also may have an impact on the inflammatory response induced by obesity (Fig. 1). Therefore, in view of the existing body of data and given that the effects of $E_{2}$ on astrocytes are sexually dimorphic $[111,112]$, further experiments on the role of estrogens in astrocyte-mediated neuroendocrine actions are warranted in

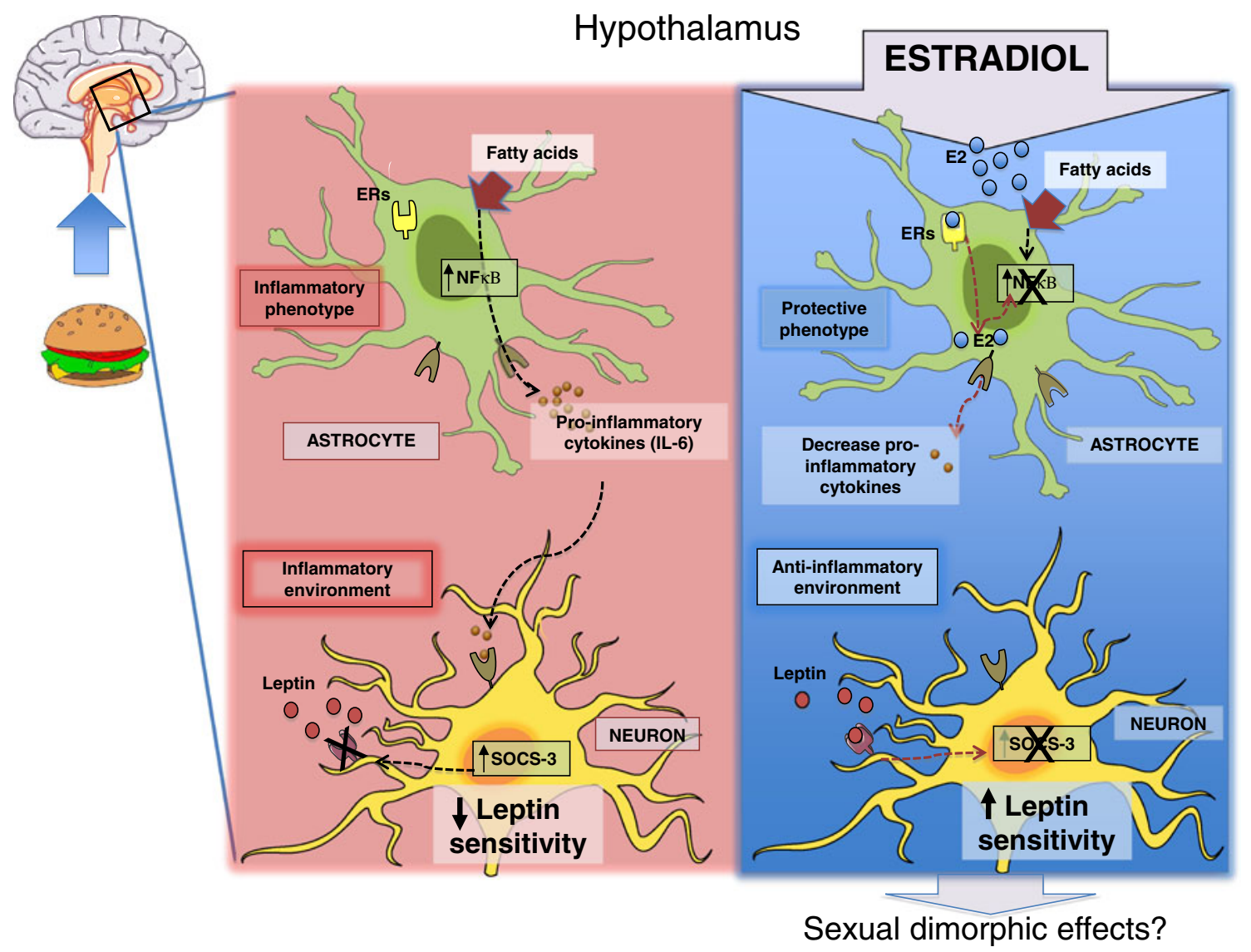

Fig. 1 Potential anti-inflammatory effects of estrogens on hypothalamic inflammatory processes induced by overnutrition. HFD feeding induces astrogliosis through activating NFKB pathway and releasing pro-inflammatory cytokines (IL-6). These astrocyte actions develop an inflammatory enviroment which could have detrimental effects on neurons such as the lack of leptin sensitivity as result of an increase in SOCS3 levels induced by inflammatory pathway activation in these cells and leading a positive energy balance. Estrogens are well-known for their protective effects in several cell types and thus, we hypothesize that estrogens could reduce astrocyte inflammatory phenotype through reducing fatty acidsactivated NFkB activity and consequently decreasing inflammatory mediators synthesis. These astrocyte effects mediated by estrogens could be behind of the restoration of leptin signaling and sensitivity in neurons. $E R s$ estrogen receptors; $E 2$ estradiol; $I L-6$ Interleukin; $N F \kappa \beta$ nuclear factor-kB; SOCS-3 suppressor of cytokine signaling 3 
order to explore the development of sex-specific therapeutics for a more personalized treatment of obesity and related metabolic disorders.

\section{Conflict of interest The authors declared no conflict of interest.}

Open Access This article is distributed under the terms of the Creative Commons Attribution License which permits any use, distribution, and reproduction in any medium, provided the original author(s) and the source are credited.

\section{References}

1. Flegal KM, Graubard BI, Williamson DF, Gail MH. Cause-specific excess deaths associated with underweight, overweight, and obesity. JAMA J Am Med Assoc. 2007;298(17):2028-37.

2. García-Cáceres C, Yi C-X, Tschöp MH. Hypothalamic astrocytes in obesity. Endocrinol Metab Clin N Am. 2013;42(1):57-66.

3. Kanter R, Caballero B. Global gender disparities in obesity: a review. Adv Nutr. 2012;3(4):491-8.

4. Lovejoy JC, Sainsbury A, Stock Conference Working G. Sex differences in obesity and the regulation of energy homeostasis. Obes Rev. 2009;10(2):154-67.

5. Iyer A, Kauter K, Brown L. Gender differences in metabolic syndrome: a key research issue? Endocr Metab Immune Disord Drug Targets. 2011;11(3):182-8.

6. Fuente-Martín E, Granado M, García-Cáceres C, Sanchez-Garrido MA, Frago LM, Tena-Sempere M, et al. Early nutritional changes induce sexually dimorphic long-term effects on body weight gain and the response to sucrose intake in adult rats. Metabolism. 2012;61(6):812-22.

7. Power ML, Schulkin J. Sex differences in fat storage, fat metabolism, and the health risks from obesity: possible evolutionary origins. Br J Nutr. 2008;99(5):931-40.

8. Sugiyama MG, Agellon LB. Sex differences in lipid metabolism and metabolic disease risk. Biochem Cell Biol. 2012;90(2):124-41.

9. Shi H, Seeley RJ, Clegg DJ. Sexual differences in the control of energy homeostasis. Front Neuroendocrinol. 2009;30(3):396-404.

10. Dubuc PU. Effects of estrogen on food intake, body weight, and temperature of male and female obese mice. Proc Soc Exp Biol Med. 1985;180(3):468-73.

11. Sharp JC, Copps JC, Liu Q, Ryner LN, Sebastian RA, Zeng GQ, et al. Analysis of ovariectomy and estrogen effects on body composition in rats by X-ray and magnetic resonance imaging techniques. J Bone Miner Res. 2000;15(1):138-46.

12. Asarian L, Geary N. Modulation of appetite by gonadal steroid hormones. Phil Trans R Soc B. 2006;361(1471):1251-63.

13. Clegg DJ, Air EL, Benoit SC, Sakai RS, Seeley RJ, Woods SC. Intraventricular melanin-concentrating hormone stimulates water intake independent of food intake. Am J Physiol Regul Integr Comp Physiol. 2003;284(2):R494-9.

14. Clegg DJ, Edwards GL, Martin RJ. Central insulin potentiates eating elicited by 2-deoxy-D-glucose. Physiol Behav. 2003;78 (2):331-6.

15. Geary N, Asarian L, Korach KS, Pfaff DW, Ogawa S. Deficits in E2-dependent control of feeding, weight gain, and cholecystokinin satiation in ER-alpha null mice. Endocrinology. 2001;142(11): 4751-7.

16. Pfaff D, Keiner M. Atlas of estradiol-concentrating cells in the central nervous system of the female rat. J Comp Neurol. 1973; 151(2):121-58.
17. Pfaff DW, Gerlach JL, McEwen BS, Ferin M, Carmel P, Zimmerman EA. Autoradiographic localization of hormoneconcentrating cells in the brain of the female rhesus monkey. J Comp Neurol. 1976;170(3):279-93.

18. Brinton RD. Estrogen-induced plasticity from cells to circuits: predictions for cognitive function. [Research Support, N.I.H., Extramural Research Support, Non-U.S. Gov't Review]. Trends Pharmacol Sci. 2009;30(4):212-22.

19. Barreto G, Santos-Galindo M, Diz-Chaves Y, Pernia O, Carrero P, Azcoitia I, et al. Selective estrogen receptor modulators decrease reactive astrogliosis in the injured brain: effects of aging and prolonged depletion of ovarian hormones. Endocrinology. 2009; 150(11):5010-5.

20. Arevalo MA, Santos-Galindo M, Bellini MJ, Azcoitia I, GarciaSegura LM. Actions of estrogens on glial cells: implications for neuroprotection. Biochim Biophys Acta. 2010;1800(10):1106-12.

21. Garcia-Ovejero D, Azcoitia I, DonCarlos LL, Melcangi RC, GarciaSegura LM. Glia-neuron crosstalk in the neuroprotective mechanisms of sex steroid hormones. Brain Res Rev. 2005;48(2):273-86.

22. GarciaSegura LM, Chowen JA, Naftolin F. Endocrine glia: roles of glial cells in the brain actions of steroid and thyroid hormones and in the regulation of hormone secretion. Front Neuroendocrinol. 1996;17(2):180-211.

23. Theodosis DT, Piet R, Poulain DA, Oliet SH. Neuronal, glial and synaptic remodeling in the adult hypothalamus: functional consequences and role of cell surface and extracellular matrix adhesion molecules. Neurochem Int. 2004;45(4):491-501.

24. Horvath TL, Sarman B, Garcia-Caceres C, Enriori PJ, Sotonyi P, Shanabrough M, et al. Synaptic input organization of the melanocortin system predicts diet-induced hypothalamic reactive gliosis and obesity. Proc Natl Acad Sci U S A. 2010;107(33):14875-80.

25. Thaler JP, Yi CX, Schur EA, Guyenet SJ, Hwang BH, Dietrich MO, et al. Obesity is associated with hypothalamic injury in rodents and humans. J Clin Investig. 2012;122(1):153-62.

26. Yi CX, Habegger KM, Chowen JA, Stern J, Tschop MH. A role for astrocytes in the central control of metabolism. Neuroendocrinology. 2011;93(3):143-9.

27. Clegg DJ, Benoit SC, Air EL, Jackman A, Tso P, D'Alessio D, et al. Increased dietary fat attenuates the anorexic effects of intracerebroventricular injections of MTII. Endocrinology. 2003;144(7):2941-6.

28. Clegg DJ, Brown LM, Woods SC, Benoit SC. Gonadal hormones determine sensitivity to central leptin and insulin. Diabetes. 2006;55 (4):978-87.

29. Taylor RW, Grant AM, Williams SM, Goulding A. Sex differences in regional body fat distribution from pre- to postpuberty. Obesity (Silver Spring). 2010;18(7):1410-6.

30. He Q, Horlick M, Thornton J, Wang J, Pierson RN, Heshka S, et al. Sex and race differences in fat distribution among Asian, AfricanAmerican, and Caucasian prepubertal children. J Clin Endocrinol Metab. 2002;87(5):2164-70.

31. Demerath EW, Sun SS, Rogers N, Lee M, Reed D, Choh AC, et al. Anatomical patterning of visceral adipose tissue: race, sex, and age variation. Obesity (Silver Spring). 2007;15(12):2984-93.

32. Goodman-Gruen D, Barrett-Connor E. Sex differences in measures of body fat and body fat distribution in the elderly. Am J Epidemiol. 1996;143(9):898-906.

33. Camhi SM, Bray GA, Bouchard C, Greenway FL, Johnson WD, Newton RL, et al. The relationship of waist circumference and BMI to visceral, subcutaneous, and total body fat: sex and race differences. Obesity (Silver Spring). 2011;19(2):402-8.

34. Frederich RC, Hamann A, Anderson S, Lollmann B, Lowell BB, Flier JS. Leptin levels reflect body lipid content in mice: evidence for diet-induced resistance to leptin action. Nat Med. 1995;1(12):1311-4.

35. Shimizu H, Shimomura Y, Nakanishi Y, Futawatari T, Ohtani K, Sato N, et al. Estrogen increases in vivo leptin production in rats and human subjects. J Endocrinol. 1997;154(2):285-92. 
36. Demerath EW, Towne B, Wisemandle W, Blangero J, Chumlea WC, Siervogel RM. Serum leptin concentration, body composition, and gonadal hormones during puberty. Int J Obes Relat Metab Disord. 1999;23(7):678-85.

37. Wu-Peng S, Rosenbaum M, Nicolson M, Chua SC, Leibel RL. Effects of exogenous gonadal steroids on leptin homeostasis in rats. Obes Res. 1999;7(6):586-92.

38. Machinal F, Dieudonne MN, Leneveu MC, Pecquery R, Giudicelli $\mathrm{Y}$. In vivo and in vitro ob gene expression and leptin secretion in rat adipocytes: evidence for a regional specific regulation by sex steroid hormones. Endocrinology. 1999;140(4):1567-74.

39. Sun WH, Keller ET, Stebler BS, Ershler WB. Estrogen inhibits phorbol ester-induced I kappa B alpha transcription and protein degradation. Biochem Biophys Res Commun. 1998;244(3):6915 .

40. Ribas V, Nguyen MT, Henstridge DC, Nguyen AK, Beaven SW, Watt MJ, et al. Impaired oxidative metabolism and inflammation are associated with insulin resistance in ERalpha-deficient mice. Am J Physiol Endocrinol Metab. 2010;298(2):E304-19.

41. Geary N, Asarian L. Estradiol increases glucagon's satiating potency in ovariectomized rats. Am J Physiol Regul Integr Comp Physiol. 2001; 281(4):R1290-4

42. Tchernof A, Calles-Escandon J, Sites CK, Poehlman ET. Menopause, central body fatness, and insulin resistance: effects of hormone-replacement therapy. Coron Artery Dis. 1998;9(8):50311.

43. Filardo EJ, Quinn JA, Frackelton AR, Bland KI. Estrogen action via the G protein-coupled receptor, GPR30: stimulation of adenylyl cyclase and cAMP-mediated attenuation of the epidermal growth factor receptor-to-MAPK signaling axis. Mol Endocrinol. 2002; 16(1):70-84

44. Welboren WJ, Sweep FC, Span PN, Stunnenberg HG. Genomic actions of estrogen receptor alpha: what are the targets and how are they regulated? Endocr Relat Cancer. 2009;16(4):1073-89.

45. Bouchard C, Despres JP, Mauriege P. Genetic and nongenetic determinants of regional fat distribution. Endocr Rev. 1993;14(1): 72-93.

46. Jones ME, Thorburn AW, Britt KL, Hewitt KN, Wreford NG, Proietto J, et al. Aromatase-deficient (ArKO) mice have a phenotype of increased adiposity. Proc Natl Acad Sci U S A. 2000; 97(23):12735-40.

47. Gao Q, Mezei G, Nie YZ, Rao Y, Choi CS, Bechmann I, et al. Anorectic estrogen mimics leptin's effect on the rewiring of melanocortin cells and Stat3 signaling in obese animals. Nat Med. 2007;13(1):89-94.

48. Xu Y, Nedungadi TP, Zhu LR, Sobhani N, Irani BG, Davis KE, et al. Distinct hypothalamic neurons mediate estrogenic effects on energy homeostasis and reproduction. Cell Metab. 2011;14(4):453-65.

49. Roepke TA. Oestrogen modulates hypothalamic control of energy homeostasis through multiple mechanisms. J Neuroendocrinol. 2009;21(2):141-50.

50. Rowland N, Meile MJ, Nicolaidis S. Metering of intravenously infused nutrients in VMH lesioned rats. Physiol Behav. 1975;15(5): 443-8.

51. Louis-Sylvestre J, Larue-Achagiotis C, Le Magnen J. Oral induction of the insulin hyper-responsiveness in rats with ventromedial hypothalamic lesions. Horm Metab Res. 1980;12(12):671-6.

52. Anand BK, Brobeck JR. Hypothalamic control of food intake in rats and cats. Yale J Biol Med. 1951;24(2):123-40.

53. Danguir J, Nicolaidis S. Cortical activity and sleep in the rat lateral hypothalamic syndrome. Brain Res. 1980;185(2):305-21.

54. Milam KM, Stern JS, Storlien LH, Keesey RE. Effect of lateral hypothalamic lesions on regulation of body weight and adiposity in rats. Am J Physiol. 1980;239(3):R337-43.

55. Cone RD, Cowley MA, Butler AA, Fan W, Marks DL, Low MJ. The arcuate nucleus as a conduit for diverse signals relevant to energy homeostasis. Int J Obes Relat Metab Disord. 2001;25 Suppl 5:S63-7.

56. Heine PA, Taylor JA, Iwamoto GA, Lubahn DB, Cooke PS. Increased adipose tissue in male and female estrogen receptor-alpha knockout mice. Proc Natl Acad Sci U S A. 2000;97(23):12729-34.

57. Ohlsson C, Hellberg N, Parini P, Vidal O, Bohlooly YM, Rudling M, et al. Obesity and disturbed lipoprotein profile in estrogen receptoralpha-deficient male mice. Biochem Biophys Res Commun. 2000;278 (3):640-5.

58. Liang YQ, Akishita M, Kim S, Ako J, Hashimoto M, Iijima K, et al. Estrogen receptor beta is involved in the anorectic action of estrogen. Int J Obes. 2002;26(8):1103-9.

59. de Souza FS, Nasif S, Lopez-Leal R, Levi DH, Low MJ, Rubinsten $\mathrm{M}$. The estrogen receptor alpha colocalizes with proopiomelanocortin in hypothalamic neurons and binds to a conserved motif present in the neuron-specific enhancer nPE2. Eur J Pharmacol. 2011;660(1):1817.

60. Wise PM, Scarbrough K, Weiland NG, Larson GH. Diurnal pattern of proopiomelanocortin gene expression in the arcuate nucleus of proestrous, ovariectomized, and steroid-treated rats: a possible role in cyclic luteinizing hormone secretion. Mol Endocrinol. 1990;4 (6):886-92.

61. Musatov S, Chen W, Pfaff DW, Mobbs CV, Yang XJ, Clegg DJ, et al. Silencing of estrogen receptor alpha in the ventromedial nucleus of hypothalamus leads to metabolic syndrome. Proc Natl Acad Sci U S A. 2007;104(7):2501-6.

62. Tartaglia LA, Dembski M, Weng X, Deng N, Culpepper J, Devos R, et al. Identification and expression cloning of a leptin receptor, OBR. Cell. 1995;83(7):1263-71.

63. Ahima RS, Kelly J, Elmquist JK, Flier JS. Distinct physiologic and neuronal responses to decreased leptin and mild hyperleptinemia. Endocrinology. 1999;140(11):4923-31.

64. Ahima RS, Prabakaran D, Mantzoros C, Qu D, Lowell B, MaratosFlier E, et al. Role of leptin in the neuroendocrine response to fasting. Nature. 1996;382(6588).

65. Elias CF, Aschkenasi C, Lee C, Kelly J, Ahima RS, Bjorbaek C, et al. Leptin differentially regulates NPY and POMC neurons projecting to the lateral hypothalamic area. Neuron. 1999;23(4): $775-86$.

66. Seeley RJ, van Dijk G, Campfield LA, Smith FJ, Burn P, Nelligan $\mathrm{JA}$, et al. Intraventricular leptin reduces food intake and body weight of lean rats but not obese Zucker rats. Horm Metab Res. 1996;28 (12):664-8.

67. Morton GJ, Niswender KD, Rhodes CJ, Myers Jr MG, Blevins JE, Baskin DG, et al. Arcuate nucleus-specific leptin receptor gene therapy attenuates the obesity phenotype of Koletsky $(\mathrm{fa}(\mathrm{k}) / \mathrm{fa}(\mathrm{k}))$ rats. Endocrinology. 2003;144(5):2016-24.

68. Schwartz MW, Porte Jr D. Diabetes, obesity, and the brain. Science. 2005;307(5708):375-9.

69. Elmquist JK, Elias CF, Saper CB. From lesions to leptin: hypothalamic control of food intake and body weight. Neuron. 1999;22 (2):221-32.

70. Schwartz MW, Woods SC, Porte Jr D, Seeley RJ, Baskin DG. Central nervous system control of food intake. Nature. 2000;404 (6778):661-71.

71. Woods SC, Schwartz MW, Baskin DG, Seeley RJ. Food intake and the regulation of body weight. Annu Rev Psychol. 2000;51:255-77.

72. Seeley RJ, Woods SC. Monitoring of stored and available fuel by the CNS: implications for obesity. Nat Rev Neurosci. 2003;4(11): 901-9.

73. Balthasar N, Coppari R, McMinn J, Liu SM, Lee CE, Tang V, et al. Leptin receptor signaling in POMC neurons is required for normal body weight homeostasis. Neuron. 2004;42(6):98391.

74. Chen H, Charlat O, Tartaglia LA, WoolfEA, Weng X, Ellis SJ, et al. Evidence that the diabetes gene encodes the leptin receptor: 
identification of a mutation in the leptin receptor gene in $\mathrm{db} / \mathrm{db}$ mice. Cell. 1996;84(3):491-5.

75. Diano S, Kalra SP, Horvath TL. Leptin receptor immunoreactivity is associated with the Golgi apparatus of hypothalamic neurons and glial cells. J Neuroendocrinol. 1998;10(9):647-50.

76. Bennett PA, Lindell K, Wilson C, Carlsson LM, Carlsson B, Robinson IC. Cyclical variations in the abundance of leptin receptors, but not in circulating leptin, correlate with NPY expression during the oestrous cycle. Neuroendocrinology. 1999;69(6):417-23.

77. Chakraborty S, Sachdev A, Salton SR, Chakraborty TR. Stereological analysis of estrogen receptor expression in the hypothalamic arcuate nucleus of ob/ob and agouti mice. Brain Res. 2008;1217:86-95.

78. Clegg DJ, Brown LM, Woods SC, Benoit SC. Gonadal hormones determine sensitivity to central leptin and insulin. Diabetes. 2006;55 (4):978-87.

79. Gao Q, Horvath TL. Cross-talk between estrogen and leptin signaling in the hypothalamus. Am J Physiol Endocrinol Metab. 2008; 294(5):E817-26.

80. Somjen GG. Nervenkitt: notes on the history of the concept of neuroglia. Glia. 1988;1(1):2-9.

81. Araque A, Sanzgiri RP, Parpura V, Haydon PG. Astrocyte-induced modulation of synaptic transmission. Can J Physiol Pharmacol. 1999; 77(9):699-706.

82. Barres BA. New roles for glia. J Neurosci. 1991;11(12):3685-94.

83. Ullian EM, Sapperstein SK, Christopherson KS, Barres BA. Control of synapse number by glia. Science. 2001;291(5504): 657-61.

84. Pellerin L, Magistretti PJ. Neuroenergetics: calling upon astrocytes to satisfy hungry neurons. Neuroscientist. 2004;10(1):53-62.

85. Tasker JG, Oliet SH, Bains JS, Brown CH, Stern JE. Glial regulation of neuronal function: from synapse to systems physiology. $\mathrm{J}$ Neuroendocrinol. 2012;24(4):566-76.

86. Dong Y, Benveniste EN. Immune function of astrocytes. Glia. 2001;36(2):180-90.

87. Takano T, Oberheim N, Cotrina ML, Nedergaard M. Astrocytes and ischemic injury. Stroke. 2009;40(3 Suppl):S8-12.

88. Fuente-Martín E, García-Cáceres C, Granado M, de Ceballos ML, Sánchez-Garrido MÁ, Sarman B, et al. Leptin regulates glutamate and glucose transporters in hypothalamic astrocytes. J Clin Investig. 2012;122(11):3900-13.

89. Fields RD, Stevens-Graham B. Neuroscience - new insights into neuron-glia communication. Science. 2002;298(5593):556-62.

90. Levin BE, Magnan C, Dunn-Meynell A, Le Foll C. Metabolic sensing and the brain: who, what, where, and how? Endocrinology. 2011;152(7):2552-7.

91. Pan W, Hsuchou H, He Y, Sakharkar A, Cain C, Yu C, et al. Astrocyte leptin receptor $(\mathrm{ObR})$ and leptin transport in adult-onset obese mice. Endocrinology. 2008;149(6):2798-806.

92. Garcia-Segura LM, Naftolin F, Hutchison JB, Azcoitia I, Chowen JA. Role of astroglia in estrogen regulation of synaptic plasticity and brain repair. J Neurobiol. 1999;40(4):574-84.

93. Azcoitia I, Sierra A, Garcia-Segura LM. Localization of estrogen receptor beta-immunoreactivity in astrocytes of the adult rat brain. Glia. 1999;26(3):260-7.

94. Pawlak J, Karolczak M, Krust A, Chambon P, Beyer C. Estrogen receptor-alpha is associated with the plasma membrane of astrocytes and coupled to the MAP/Src-kinase pathway. Glia. 2005;50(3):270 5 .

95. Quesada A, Romeo HE, Micevych P. Distribution and localization patterns of estrogen receptor-beta and insulin-like growth factor-1 receptors in neurons and glial cells of the female rat substantia nigra: localization of ERbeta and IGF-1R in substantia nigra. J Comp Neurol. 2007;503(1):198-208.

96. Chaban VV, Lakhter AJ, Micevych P. A membrane estrogen receptor mediates intracellular calcium release in astrocytes. Endocrinology. 2004;145(8):3788-95.
97. Ridet JL, Alonso G, Chauvet N, Chapron J, Koenig J, Privat A. Immunocytochemical characterization of a new marker of fibrous and reactive astrocytes. Cell Tissue Res. 1996;283(1):39-49.

98. Levine JB, Kong J, Nadler M, Xu Z. Astrocytes interact intimately with degenerating motor neurons in mouse amyotrophic lateral sclerosis (ALS). Glia. 1999;28(3):215-24.

99. Hertz L, McFarlin DE, Waksman BH. Astrocytes: auxiliary cells for immune responses in the central nervous system? Immunol Today. 1990;11(8):265-8.

100. Pan W, Hsuchou H, Xu C, Wu X, Bouret SG, Kastin AJ. Astrocytes modulate distribution and neuronal signaling of leptin in the hypothalamus of obese A vy mice. J Mol Neurosci. 2011;43(3):478-84.

101. Kuo J, Hariri OR, Bondar G, Ogi J, Micevych P. Membrane estrogen receptor-alpha interacts with metabotropic glutamate receptor type 1a to mobilize intracellular calcium in hypothalamic astrocytes. Endocrinology. 2009;150(3):1369-76.

102. Micevych P, Bondar G, Kuo J. Estrogen actions on neuroendocrine glia. Neuroendocrinology. 2010;91(3):211-22.

103. Micevych P, Soma KK, Sinchak K. Neuroprogesterone: key to estrogen positive feedback? Brain Res Rev. 2008;57(2):470-80.

104. Micevych PE, Chaban V, Ogi J, Dewing P, Lu JK, Sinchak K. Estradiol stimulates progesterone synthesis in hypothalamic astrocyte cultures. Endocrinology. 2007;148(2):782-9.

105. Irwin RW, Yao J, To J, Hamilton RT, Cadenas E, Brinton RD. Selective oestrogen receptor modulators differentially potentiate brain mitochondrial function. J Neuroendocrinol. 2012;24(1):23648.

106. Revankar CM, Cimino DF, Sklar LA, Arterburn JB, Prossnitz ER. A transmembrane intracellular estrogen receptor mediates rapid cell signaling. Science. 2005;307(5715):1625-30.

107. Thomas P, Pang Y, Filardo EJ, Dong J. Identity of an estrogen membrane receptor coupled to a $\mathrm{G}$ protein in human breast cancer cells. Endocrinology. 2005;146(2):624-32.

108. Kuo J, Hamid N, Bondar G, Prossnitz ER, Micevych P. Membrane estrogen receptors stimulate intracellular calcium release and progesterone synthesis in hypothalamic astrocytes. J Neurosci. 2010;30(39):12950-7.

109. Bondar G, Kuo J, Hamid N, Micevych P. Estradiol-induced estrogen receptor-alpha trafficking. J Neurosci. 2009;29(48):15323-30.

110. Kuo J, Hamid N, Bondar G, Dewing P, Clarkson J, Micevych P. Sex differences in hypothalamic astrocyte response to estradiol stimulation. Biol Sex Differ. 2010;1(1):7.

111. McCarthy MM, Amateau SK, Mong JA. Steroid modulation of astrocytes in the neonatal brain: implications for adult reproductive function. Biol Reprod. 2002;67(3):691-8.

112. Mong JA, Blutstein T. Estradiol modulation of astrocytic form and function: implications for hormonal control of synaptic communication. Neuroscience. 2006;138(3):967-75.

113. De Marinis E, Acaz-Fonseca E, Arevalo MA, Ascenzi P, Fiocchetti M, Marino M, et al. 17beta-oestradiol anti-inflammatory effects in primary astrocytes require oestrogen receptor beta-mediated neuroglobin up-regulation. J Neuroendocrinol. 2013;25(3):260 70 .

114. Azcoitia I, Santos-Galindo M, Arevalo MA, Garcia-Segura LM. Role of astroglia in the neuroplastic and neuroprotective actions of estradiol. Eur J Neurosci. 2010;32(12):1995-2002.

115. Guo J, Duckles SP, Weiss JH, Li X, Krause DN. 17beta-Estradiol prevents cell death and mitochondrial dysfunction by an estrogen receptor-dependent mechanism in astrocytes after oxygen-glucose deprivation/reperfusion. Free Radic Biol Med. 2012;52(11-12):215160.

116. Cerciat M, Unkila M, Garcia-Segura LM, Arevalo MA. Selective estrogen receptor modulators decrease the production of interleukin6 and interferon-gamma-inducible protein-10 by astrocytes exposed to inflammatory challenge in vitro. Glia. 2010;58(1):93-102. 
117. Tenenbaum M, Azab AN, Kaplanski J. Effects of estrogen against LPS-induced inflammation and toxicity in primary rat glial and neuronal cultures. J Endotoxin Res. 2007;13(3):158-66.

118. Dodel RC, Du Y, Bales KR, Gao F, Paul SM. Sodium salicylate and 17beta-estradiol attenuate nuclear transcription factor NF-kappaB translocation in cultured rat astroglial cultures following exposure to amyloid A beta(1-40) and lipopolysaccharides. J Neurochem. 1999;73(4):1453-60.

119. Garcia-Segura LM, McCarthy MM. Minireview: role of glia in neuroendocrine function. Endocrinology. 2004;145(3):10826 .
120. Lee E, Sidoryk-Wegrzynowicz M, Wang N, Webb A, Son DS, Lee $\mathrm{K}$, et al. GPR30 regulates glutamate transporter GLT-1 expression in rat primary astrocytes. J Biol Chem. 2012;287(32):2681728.

121. Matyskova R, Zelezna B, Maixnerova J, Koutova D, Haluzik M, Maletinska L. Estradiol supplementation helps overcome central leptin resistance of ovariectomized mice on a high fat diet. Horm Metab Res. 2010. doi:10.1055/s-0030-1247520.

122. Finan B, Yang B, Ottaway N, Stemmer K, Muller TD, Yi CX, et al. Targeted estrogen delivery reverses the metabolic syndrome. Nat Med. 2012;18(12):1847-56. 